\title{
IFRS and Secrecy: Assessing Accounting Value Relevance Across Africa
}

David Hillier, University of Strathclyde Business School, Glasgow, Scotland, U.K.

Email: david.hillier@strath.ac.uk

Allan Hodgson, University of Queensland Business School, St Lucia, Queensland, Australia

Email: a.hodgson@business.uq.edu.au

Shaban Ngole, Institute of Finance Management, Dar Es Salaam, Tanzania

Email:n.gole@hotmail.co.uk

\begin{abstract}
We examine the value relevance of accounting across several African countries and test whether IFRS improved the value association of earnings and equity book values. We find a stronger valuation association between accounting and stock prices in African countries classified as having a secrecy culture. This increases after IFRS and more so for earningslikely explained by opaque and illiquid asset markets that gain little from the revaluation balance sheet focus of IFRS. On the other hand, IFRS induced a stronger increase in the book value coefficient in the less secretive and more developed South African market. Commonly used legal based control variables showed little marginal explanatory power. A possible driver is that the more conceptual focus of IFRS induced an increased demand for higher quality accounting professionals, and this had a filtering down effect of improving managerial decision making. Our research highlights the diverse impacts of IFRS and the role of culture, asset markets and accounting professionalism, in driving the relevance of accounting components across Africa.
\end{abstract}

Keywords IFRS value relevance, African accounting response coefficients, Culture, secrecy and IFRS.

JEL Classification G14. M40. M41

The authors acknowledge seed funding from an International Association for Accounting Education and Research (IAAER) grant issued in partnership with ACCA. Feedback from participants at the Southern African Accounting Association (SAAA) in Cape Town (June, 2013), the International IFRS Symposium in Santiago de Cali Colombia (November, 2012), the IX Workshop on Empirical Research in Financial Accounting, the V Research Forum of the Spanish Journal of Finance and Accounting in Gran Canaria (October 2012), and the International Conference on Policy Development in Dar Es Salaam, Tanzania (August 2012), is gratefully acknowledged. The paper was also significantly improved by review comments received from Mary Barth, Tom Van Caneghem, Immanuel Mnzava, two anonymous reviewers of this journal and the editor, Sidney Gray. 


\section{Introduction}

The valuation impact of International Financial Reporting Standards (IFRS) on capital markets is now a fundamental international issue with over one hundred and twenty countries adopting IFRS. These countries include both developed and under-developed economies. Whilst IFRS is arguably an important innovative change aimed at raising the quality of accounting standards, several commentators question the economic importance of accounting quality. For example, Zimmerman (2013) argues that external financial reporting quality has only a small second order effect on firm stock value in the U.S.- - with improvements having a lower third order effect. ${ }^{1}$

The question we ask is whether accounting in general and the introduction of IFRS, play a significant firm valuation role in under-developed markets. If accounting “improvements" are more important in under-developed countries, then Ball (2006) ponders whether the introduction of IFRS across heterogeneous business, political, legal and cultural environments, obscures real valuation signals. Hence, our general contribution is to examine if accounting has value relevance across several African countries and to examine the marginal impact of IFRS.

There are several practical reasons why this is important. The first is the potential role of accounting in supporting decision making. The International Accounting Standards Board (IASB) has an objective function to develop a set of high quality, understandable, enforceable and globally accepted IFRS, to help participants in the world's capital markets to improve economic decisions. Daske and Gebhardt (2006) claim that IFRS provides better quality outputs compared to local GAAP — thus, providing an information price externality to investors. If pre-IFRS Africa has less sophisticated accounting systems, then the externality to investors will be higher. Second, accounting plays an internal decision making and feedback role. For example, accounting numbers are used as benchmarks to align managers to firm performance, as performance incentives, and to mitigate agency conflicts between managers, investors and bondholders. In essence, informing management on relative sector (resource) efficiency and providing numbers for agency contracts.

There is also the pragmatic question of the cost/benefit trade-off from a more complex accounting system. IFRS requires asset/liability re-measurements through the use of fair

\footnotetext{
${ }^{1}$ First order effects being (amongst others): the quality of management and human resources, operational efficiency, the competitiveness of products and services, the internal incentive system, and the firm's regulation and tax environment.
} 
value techniques, the recognition of gains and losses in comprehensive income, and continuous impairment monitoring. These activities require regular information about market prices and, if not available, re-measurements calculated by a 'suitably' trained accountant. ${ }^{2}$ This process is complex which requires re-education or the importation of higher quality accountants - both require additional costs. However, if economic events are translated into greater fundamental accounting numbers and this improves the mapping from accounting to future cash flows, then it (possibly) provides a positive benefit/cost trade-off to investors and managers.

On the other hand, whether this occurs in under-developed markets is questioned by several authors. This is because they are distinguished by lower levels of financial market development, greater agency problems, lower managerial accountability, corruption and opaque business practices. In this context, Ball (2008) argues that the greater reliance by IFRS on fair value accounting is inappropriate for countries with illiquid stock markets, asset price in-effectiveness, and higher managerial/shareholder agency conflicts. Given these attributes along with the increased subjectivity within IFRS, the role of accounting in uncertainty resolution of future cash flows is reduced (Penman and Yehuda 2015). In summary, valuation, efficiency, contracting, and feedback issues of accounting are particularly important in countries that have lower secondary levels of information feedback from financial analysts, institutional investors, and the media.

One approach to conditionally assess accounting quality feedback is to control for legal constructs. Code law as a proxy for unconditional conservative accounting deemed to be of lower quality when compared to common law; and second, rule of law which represents the degree to which society effectively enforces accounting standards (Preiato et al. 2014). We apply both, but additionally construct a secrecy index based on Hope et al. (2008), influenced by several of Hofstede’s cultural proxies (Hofstede 1980, 2001). Cultural values

\footnotetext{
${ }^{2}$ A three-tier fair value hierarchy is used to describe how to value assets and liabilities. Tier 1 allows the use of current/historical costs or market selling prices to value assets and liabilities. Tier 2 is derivative valuation estimating values from substitutes or similar assets/liabilities identified by Tier 1 adjusted as appropriate for differences. Tier 3 applies expectation based models (e.g. option pricing, discounted future cash flows) to derive value. More recently, in IFRS 13, fair value is defined as 'a price that would be received to sell an asset or paid to transfer a liability in an orderly transaction between market participants at the measurement date'. In short, valuations primarily based on current or expected present value.
} 
influence accounting information relevance (Hope 2003b), and Africa represents a diversity in business culture. ${ }^{3}$

Secrecy, as a derivative of culture, provides a particularly interesting scenario. If a secrecy culture represents unaccountable managers who are able to manipulate accounts to channel resources (and hide inefficiencies), then financial accounting reports contain no (or little) value relevant information. On the other hand, if financial accounting represents one of the few avenues for governance control and information flow, then financial reports (may) contain a valuable source of price related information. Further, comparing IFRS with preexisting African GAAP provides a natural research experiment on relative change impact, and a lens into whether IFRS reduces or increases any cultural constraints.

Using balanced panel regressions for 347 firms across Botswana, Egypt, Kenya, Morocco, and South Africa over the 2002-2009 period, we find significant aggregate value relevance for book and earnings coefficients. IFRS adoption resulted in increased book response coefficients with little impact on the earnings response coefficient-not unlike the majority of European research. Decomposing the data along secrecy and non-secrecy lines, the earnings coefficients were comparatively and significantly higher for secretive African countries and after IFRS, the secrecy earnings level coefficient had a much stronger relative increase. Legal origin proxies showed little marginal explanatory power. Hence, financial accounting plays a significant role in providing value relevant information in Africa capital markets, but in varied ways. One interpretation is that increased training and professionalism of accountants may play a secondary supporting role.

The remainder of the paper is now constructed as follows. Section 2 provides a background review of relevant literature, Section 3 outlines the research questions, and Section 4 presents the data and research methods. Section 5 reports empirical results and robustness tests and Section 6 concludes the paper.

\footnotetext{
${ }^{3}$ In pre-IFRS Africa there were competing colonial administrative structures which, in turn, imparted diverse business cultures and heterogeneous accounting standard interpretations (Gray 1988, Chamisa 2000). For example, with more developed equity markets (and common law structures), some African countries had lower levels of unconditional conservatism, whilst others had an historic cost rules based approach predicated by code law interpretations and a secretive culture.
} 


\section{Background Literature}

\subsection{Adopting IFRS}

A stated objective of the International Accounting Standards Board (IASB) is that IFRS should enhance financial information flow from firms which increases the pricing efficiency of global markets (Schipper 2005, Barth 2006, Daske and Gebhardt 2006, IASB 2010, Brown 2011). Potential valuation benefits of IFRS result from a reduction in discretionary accounting rules (relative to local GAAP) and from the application of contemporary 'fair values' that better map fundamental economic values (Dye and Sridhar 2004, Barth et al. 2008, Ding et al. 2009). ${ }^{4}$ Furthermore, improvements in accounting quality are deemed to result in a 'comparability externality' as individual firm financial reports become more price relevant and provide synchronicity in information flow across security markets.

In short, under this scenario, the adoption of IFRS would induce a stronger mapping between accounting numbers and stock prices-resulting in empirically observable increases in book and earnings valuation coefficients. Consequently, if African countries have lower quality accounting standards (such as those produced by [technical] rules based accounting), then investors in Africa may benefit from the introduction of a theoretically higher quality IFRS accounting system (Barth 2007).

On the other hand, Ball et al. (2003) caution that the accounting system may not always play a primary information and valuation role, because accrual levels are a complex component of firm specific agency factors and country-wide culture and governance. In essence, IFRS may obfuscate real differences rather than help (Ball 2006). Moreover, Zimmerman (2013) argues that improvements in external financial reporting quality are economically of little importance. They only provide a third-order impact on firm value with operating and managerial factors more significant. In addition, Prather-Kinsey (2006) argues that in countries with a high level of family ownership and political network interplays, value relevant information is channeled through an insider access model rather than through financial reporting (see also Piotrowski and Wong 2010, and He et al. 2012 for similar results in China). Hence, the problem of identifying the effects of valuation changes from IFRS adoption across African countries, with a common problem of under-developed markets but

\footnotetext{
${ }^{4}$ Fair value measurement was introduced with explicit reference to the clearly stated reporting objective: the provision of information to investors to enhance the assessment of amounts, timing and uncertainty of future cash flows from an investment in a firm's shares or debt securities (SFAC No. 1, para. 37 (FASB, 1978); IASB Framework, para. 15 (IASCB, 1989).
} 
with cross-sectional heterogeneity in legal background and culture, represents our research motivation.

\subsection{IFRS value relevance research}

Pre-IFRS accounting valuation research reported a weak association between stock prices and earnings prepared under local rules based accounting GAAP (Kothari 2001) and declining value relevance of earnings (Francis and Schipper 1999). Lev (1989) suggested this was caused by the poor information quality of historical cost accounting and a number of contemporary values (including intangibles) being left off the balance sheet. The advent of IFRS, with the ability to update using fair values, provided the opportunity to assess comparative value relevance.

Post-IFRS research is now extensive, mainly focused on Europe or more developed markets with somewhat mixed results. Single country research supporting increased value relevance after IFRS, includes Tsalavoutas et al. (2010, Greece), Jermakowicz et al. (2007, Germany), Beckman et al. (2007, Germany), and Bartov et al. (2005, Germany). Research reporting reduced or unchanged value relevance includes Lantto (2007, Finland) and Hung and Subramanyam (2007, Germany). Outside Europe, Liu and Liu (2007, China) report increased value relevance, with Lin and Chen (2005, China) and Eccher and Healy (2003, China) reporting reduced value relevance. Finally, Alali and Foote (2012, Abu Dhabi) and Bissessur and Hodgson (2012, Australia) report initial improvement followed by a decline.

Comparative European country-wide studies likewise provide a mixture. Bartov et al. (2005) report that earnings response coefficients (ERCs) are highest for firms applying USGAAP compared to IFRS, and Aubert and Grudnitski (2011) in a study of 13 European countries, examined timeliness, value relevance, and accrual quality and reported no positive incremental impact from IFRS. However, when extended to wider international comparison some similarities emerge. Notably, value relevance improves most significantly when there are larger differences between IFRS and local GAAP and strong legal enforcement and implementation (Florou and Pope 2012, Landsman et al. 2012, DeFond et al. 2011, Li 2010, Daske et al. 2008,). As a final caveat, Bruggermann et al. (2013) conclude overall increased value relevance but suggest that IFRS results should be cautiously interpreted due to the short time horizon and overstated results because of a focus on large firms.

Our focus is on Africa, where firm size is smaller and there are concerns about regulation and enforcement. The Prather-Kinsey (2006) study, on South Africa and Mexico, 
reported that whilst earnings and equity book values are value relevant in both countries, the switch away from local GAAP increased explanatory power of earnings only in Mexico-due to convergence with U.S. GAAP. Similarly, Negash (2008) and Barton et al. (2010) found that IFRS did not improve the value relevance of accounting in South Africa. Our research extends the research outside South Africa and adds the intervening impacts from three institutional factors - code and common law accounting systems (differential IFRS impact), the rule-of-law dichotomy (legal enforcement), and secrecy (other cultural impacts).

\subsection{Institutional influences}

Africa does not consist of homogeneous countries derived from common legal and business cultures. Consequently, as long as accounting reports are affected by economic, legal, political, and financial systems, it is also likely to be affected by cultural norms (Verma and Gray 1998, Gray and Vint 1995, Gray 1988, Hofstede 1980). Papadaki (2005, p.356) states '...local accounting standards are the result of a complex interaction of cultural, historical, economic, and institutional factors.' An even stronger viewpoint is put forward by Stulz and Williamson (2003) and Ding et al. (2005), who suggest that culture dominates business institutions in determining accounting standards.

In addressing institutional factors and as a proxy for the relative difference between IFRS and local domestic GAAP, a common approach is to decompose results by common and code law accounting origins. The accepted view is that common (code) law countries are associated with higher (lower) quality accounting regimes (see Barth et al. 2008, Lantto 2007)_common law accounting having a greater relationship with equity financing and contemporary market based valuations. A legal origins approach, however, may be incomplete without consideration of enforcement by using a country wide rule-of-law metric (Dam, 2006). The argument is that a common law/code law dichotomization, as a measure of investor protection, is insufficient because it does not capture the overall role of institutional governance. Moreover, Dam (2006) argues that they complement and strengthen each other. In common with prior international research we test for both interactions.

Our final approach is to apply a secrecy index used by Hope et al. (2008), and based on the seminal work of Gray (1988) who linked accounting practices to cultural proxies such as conservatism, professionalism, masculinity, uncertainty, individualism and power. The papers of Akman (2011), Ding et al. (2005), Doupnik and Tsakumis (2004), Hope (2003b), 
Dahawy et al. (2002), Jaggi and Low (2000), Gray and Vint (1995), and Chow et al. (1995) investigate (various) individual relationships between these variables and accounting quality.

The Hope et al. (2008) secrecy index is derived from an algorithm between uncertainty avoidance, power distance, and individualism traits to classify countries (see Appendix 1). Hope et al. (2008) used the secrecy index in an international comparative study of 37 countries to report a negative relationship between secretive cultures and the appointment of a big four audit firm. ${ }^{5}$ In an African study, Dahawy et al. (2002) report the secretive culture embedded in Egypt adversely affected the disclosure level of companies. There is also a possible overlap between secrecy and legal origin with Jaggi and Low (2000) reporting that secrecy is significantly associated with accounting quality in code law countries.

In summary, there are several general research questions to consider in African countries. First, does accounting have a significant impact on stock price values and did the advent of IFRS incrementally increase this valuation role? Second, did IFRS have a greater impact in common or code law countries and is rule-of-law a valuation driver? Third, what impact does a secretive culture have on accounting value relevance? These research questions are particularly important in under-developed African capital markets that seek to improve managerial operations and attract scarce investment capital. More focused research questions are now developed.

\section{Research Questions}

Prior to IFRS, accounting standards in Africa were largely based on generally accepted rules based cost accounting principles (GAAP); commonly criticised because of a focus on earnings as the valuation mechanism with the outdated residual balance sheet having little association with current prices. Moreover, Kothari (1992) and Kothari and Sloan (1992) even argue a limited association between GAAP earnings and stock prices; attributable to a myriad of conventions that include conservative revenue recognition and expense matching on obsolete costs. In contrast, the IASB (2010) Conceptual Framework emphasizes the statement of financial position as the primary valuation statement with regular re-valuations recognised in the financial statements.

\footnotetext{
${ }^{5}$ Higher quality audit firms do accept audit engagements in secretive societies, but only with increased fees to compensate for the lower quality of accounting reports.
} 
Thus, if the application of IFRS incorporates a greater degree of market-based information, is future-oriented, contains less conservative rules, and offers reduced opportunistic discretion in estimating accruals-then post-IFRS earnings should have a stronger association with a firm's underlying economics. In this case, the application of IFRS in African capital markets might lead to an incrementally stronger association between earnings and stock prices (Barth et al., 2008). A counter-veiling concern is that re-valuation gains/losses booked through other comprehensive income raises the possibility of increased accounting manipulation in countries that have capricious asset prices, manager-agent conflicts, and under-developed stock markets. This leads to a first research question:

\section{RQ1: Does the Earnings Response Coefficient increase after African IFRS adoption?}

Under the IASB (2010) Conceptual Framework, balance sheet solvency is stated as the primary valuation attribute, with the income statement the link between assets and liabilities valued at fair values (SFAS 157, IFRS 13); supported by the research of Francis and Schipper (1999) who report the valuation role of the balance sheet has increased over time. Mirroring the IASB arguments that a statement of financial position, based on conceptual and contemporary principles, represents a more fundamental and contemporary value relationship than local African GAAP, then the relationship between net book and market value of equity might increase post-IFRS. Hence our second research question is:

RQ2: Does the Book Value Response Coefficient increase after African IFRS adoption?

If assets and liabilities under IFRS produce more informative market-based valuations with changes flowing through the income statement, ceterus paribus, then both earnings and book value response coefficients might increase after IFRS and improve the explanatory power of the response models (Lev 1989). Our third research question therefore examines joint effects:

RQ3: Do both Earnings and Book Value Response coefficients contemporaneously increase after African IFRS adoption?

Legal origin is commonly applied in international accounting research as a proxy for shareholder and creditor protection, the depth of capital markets, and the quality of accounting and financial systems. Common law countries are characterized by a relatively higher level of investor and creditor protection, have a greater depth of capital markets, 
reliant on shareholder equity, and more likely to supply more informative accounting reports (Ball et al. 2000, La Porta et al. 1998, 1999).

In contrast, code law countries are reliant on bank finance, are stakeholder oriented, and are more likely to supply conservative accounting reports (Hung and Subramanyam 2007). A further consideration is that code law countries have a greater proportion of family firm ownership, with price sensitive information privately channelled through internal family networks. That is, the conservative information requirements of banks and the informal insider information networks dominate in code law countries-in turn, reducing the demand (and reliance) on updated contemporary accounting information.

However, the directional impact of IFRS across the common/code law dichotomy in Africa is unclear. IFRS could either provide a greater increase in value relevant information in African code law countries (as argued by the World Bank 2010a, Anandarajan and Hasan, 2010, and Walker 2010), or produce incrementally more value relevant information in common law African countries. It may also be insufficient if it does not capture the overall role of country wide institutional governance-that is the enforcement of accounting standards through the strength of rule-of-law. Hope (2003) states that the need for enforcement will be greater where accounting standards are more flexible and subjective, but this may be the case either under a code or common law classification. We therefore pose two research questions about country wide legal aspects:

RQ4: Is the incremental value relevance association of IFRS greater in code law or common law African countries?

RQ5: Is the incremental value relevance association of IFRS greater in African countries with stronger legal enforcement?

Our final research question is based on a secrecy index which is derived from an aggregation of cultural issues. Countries with higher levels of uncertainty avoidance and power distance in combination with lower individualism, have more secretive cultures (Gray 1988) — we add to studies that link secrecy with accounting disclosure (per Hope et al. 2008, Risberg 2005, Dahawy et al. 2002, Jaggi and Low 2000). Risberg (2005) argues that secretive cultures facilitate an increased ability to undertake manipulative earnings and asset values in order to avoid accountability to external investors. Therefore, if a secrecy culture represents unaccountable managers who manipulate accounts to channel resources and hide inefficiencies, then financial accounting reports represent a reduction in value relevant information. From an equity investor perspective, a secretive culture induces information 
asymmetry by reducing the quality of accounting. In turn, translating into greater information risk to investors, who then demand higher rates of return-resulting in lower net present values and reduced earnings and book value response coefficients. On the other hand, if financial accounting reports represent one of the few avenues for external governance to reduce agency costs in secretive cultures, then financial reports contain an incremental source of price related information.

The question then is whether IFRS results in a higher level of information disclosure and this mitigates the influence of a secretive culture on earnings and book value response coefficients. In this regard, Barth et al., (2008) argue that IFRS holistically improves the value relevance of accounting information. The means by which this may occur are not made clear. However, one possibility is an increased demand and employment of higher quality accountants who upgrade the external financial reports along with the internal feedback loop (see Albu et al. 2011). For example, IFRS could induce a first order result through the audit function, improved managerial decision making, and through the contracting role that upgrades agency alignments. In this sense, secrecy as a derivative of culture provides particularly interesting scenarios with regard to the valuation role of accounting, which leads to our final research question:

RQ6: Is accounting value relevant in secretive African cultures and did IFRS have a greater impact in countries with secretive cultures?

\section{Data and Research Method}

\subsection{Data}

The data is from 2002 to 2009, during which time twenty African countries adopted IFRS (see Appendix 2). Out of the twenty countries, our selection criteria were (i) it has a stock market, and (ii) the country required all listed firms to use IFRS. Eleven countries required full adoption, and out of these eleven, six countries had incomplete data or did not have a stock market. This left South Africa, Egypt and Kenya who adopted IFRS in 2005, and Botswana and Morocco who adopted IFRS in 2006 and 2008.

Within each country, a balanced sample was collected for all firms that had uninterrupted financial accounting and market data available within the 2002-2009 period. This filter resulted in 347 listed companies [Morocco (24), Kenya (24), Botswana (17), Egypt (40) and South Africa (242)], with total firm year observations of 2,776 ranging from 136 for 
Botswana to 1,936 for South Africa. The financial data for South Africa, Morocco and Egypt was obtained from Thomson One Banker (Worldscope), and hand-collected for Botswana and Kenya from www.Africanfinancials.com and individual company websites. All share price data was collected from DataStream, except for Botswana where the data was obtained from the Botswana Stock Exchange. Exchange rates (local currency unit per US dollar period average) were obtained from the World Bank (2010b) and all variables winsorized at $5 \%$ to mitigate the effect from outliers. The rule-of-law data was obtained from the Kaufman Governance Database and cultural variables from Hofstede (1980, 2001).

Table 1 presents a breakdown of the industry distribution by country. Non-financial firms dominate with $81 \%$ of all observations and relatively consist of manufacturing and distribution (39\%), mining (10\%), communication and logistics (6\%), hotels and tourism (5\%), construction (5\%), with combined minor sectors (35\%). Financial firms number 67, of which 33 are banks. A notable feature is that South Africa has a large group of mining firms with operations across the whole African continent. South Africa is also the financial capital of Africa and this is reflected in the greater weighting of financial firms in this country.

Table 2 presents descriptive statistics. Post IFRS, mean earnings per share, book value of equity per share, firm size and revenue growth increase significantly along with reduced leverage. Most variables have a degree of right skewness before and after IFRS, consistent with Ball et al. (2003) for East Asian countries. Table 3 reports pairwise correlation coefficients_-characterized by a positive and statistically significant correlation between the main variables of earnings, book value and stock price. Firm size has a positive correlation with all measures, except leverage, which is not significantly correlated with any other variable, except negatively with size.

\subsection{Research Method}

\section{Base Valuation Model}

It is made clear by the IASB Conceptual Framework objectives (IASB 2010) that IFRS should be relevant to the economic decisions of capital market participants. In the EU only listed firms are required to report under IFRS, explicitly recognizing the importance of investors in stock markets as primary users (see Pope and McLeay, 2011 for a discussion). Finally, IASB 2010 maintains that a combination of the stock and flow of accounting measures will broadly satisfy the information needs of investors. 
Given the IASB arguments, the clean surplus association model, derived from the predicted residual income model of Ohlson (1995) and Feltham and Ohlson (1995), provides a stock and flow test of value relevance from accounting variables. The Ohlson clean surplus model applies linear information dynamics to capture the theoretical inputs from the net book value of assets (stock), current earnings (flow) and "other information components" to estimate the price of stock. The other information component, however, is often omitted due to this variable being a priori unknown-despite Ohlson's contention that it would improve the prediction of future earnings.

Several attempts have been made to proxy "other information components". Dechow et al. (1999) added analyst forecasts as the other information component better able to forecast next years' earnings. In more recent papers, Shan et al. (2014), Ohlson (2009) and Ohlson and Juettner-Nauroth (2004), provide a theoretical link between changes in current earnings in forecasting next years' earnings based upon earnings sustainability. Moreover, given the recent empirical research by Bradshaw et al. (2012) and Lorek and Pagach (2014) that past earnings innovations outperform analyst forecasts over longer periods particularly in less traded stocks-combined with the fact that analyst following in Africa is thin-we use both past earnings levels in combination with earnings changes as proxy for the permanence or reversion in earnings. The result is a version of the Ohlson (1995) model that adds an annualized version of Foster’s (1977) innovation earnings model: ${ }^{6}$

$$
P_{i, t}=\alpha_{0}+\alpha_{1} B V_{i, t}+\alpha_{2} E_{i, t}+\alpha_{3} \Delta E_{i, t}+\varepsilon_{i, t}
$$

Dummy variables are then added to capture the significance of IFRS along with three firm control variables that are hypothesized to affect price, as follows:

$$
P_{i, t}=\alpha_{0}+\alpha_{1} D_{i, t}+\alpha_{2} B V_{i, t}+\alpha_{3} D^{*} B V_{i, t}+\alpha_{4} E_{i, t}+\alpha_{5} D^{*} E_{i, t}+\alpha_{6} \Delta E_{i, t}+\alpha_{7} D^{*} \Delta E_{i, t}+\sum C V s+\varepsilon_{i, t}
$$

where $P_{i, t}$ is the price per share of the firm three months after the balance sheet date to match the general release of accounting information, ${ }^{7} B V_{i, t}$ is the current net book value per share,

\footnotetext{
${ }^{6}$ See also, Francis and Schipper (1999) and Hung and Subramanyam (2007) for association models that apply annual change in earnings. This approach is also consistent with the fundamental analysis approach of Piotroski (2000) and Piotroski and So (2012) who use revisions in earnings and find the highest F-score is in slow information dissemination environments and for firms with limited analyst following.

${ }^{7} \mathrm{~A}$ lag period of three months is commonly used in association studies (amongst others see Barth et al. (2008) and Barth et al. (2012)). For robustness, we also lag by four months to ensure capture of the past year accounting reports.
} 
and $E_{i, t}$ and $\Delta E_{i, t}$ are the earnings per share and change in earnings per share respectively. $D$ is a dummy equal to 1 if a firm observation is from the years following the IFRS adoption year and 0 otherwise and $\varepsilon_{i, t}$ is the random error term. The ERC is measured by $\left[\alpha_{4}+\alpha_{6}\right]$ before and $\left[\left(\alpha_{4}+\alpha_{5}\right)+\left(\alpha_{6}+\alpha_{7}\right)\right]$ after IFRS respectively, and the BRC by $\alpha_{2}$ before IFRS adoption and $\left[\alpha_{2}+\alpha_{3}\right]$ after IFRS.

Prior studies show that a number of firm specific factors have an impact on the value relevance of the earnings response coefficient (ERC) and book response coefficient (BRC). Consistent with Barth et al., (2008), we include firm size, financial leverage and firm growth as control variables. FIRM SIZE is defined as the natural logarithm of total assets. If larger firms attract the greater attention of institutional investors, the financial press and financial analysts, then closer monitoring might ensure a higher quality of earnings with the ERC positively related to firm size. $L E V$ is defined as the ratio of total liabilities to net book value of equity and proxies for firm risk (Barth et al. 2008, Hung and Subramanyam 2007). As leverage increases so does bankruptcy and liquidation risks, in turn, inducing a possible increase in accounting management and an inverse relation between the BRC and ERC and financial leverage. Finally, GROWTH is defined as the change in sales divided by total assets (Barth et al. 2008). For a firm with growth options, the expected return from profitable investment opportunities exceeds the risk-adjusted rate of return. Hence, if the present value of the expected future cash flows is increased this leads to a positive association with the ERC.

We run ordinary least square regressions and fixed effect regressions that additionally control for firm year and country fixed effects. Whilst we included before and after dummies for IFRS, by adding firm fixed effects we additionally allow for omitted variables that exert a common annual impact on all countries (e.g. pre and post the global financial crisis). To reduce the effect of heteroskedasticity, all variables are scaled by beginning period stock price and winsorized at the $5 \%$ level to mitigate the influence of extreme observations. In all regressions, heteroskedasticity and multicollinearity is checked using the Breusch Pagan, Cook Weisberg, and Variance Inflation Factors (VIF) tests.

\section{Law and Governance}

In order to examine the impact of legal and rule-of-law enforcement on the value relevance of the ERC and the BRC before and after IFRS, we divide the sample into common and code 
law countries and introduce the legal origin dummy, $\mathrm{C}$, on the test variables in equation 1 to form the following dummy variable model:

$$
\begin{aligned}
& P_{i, t}=\alpha_{0}+\alpha_{1} D_{i, t}+\alpha_{2} C_{i, t}+\alpha_{3} B V_{i, t}+\alpha_{4} C^{*} B V_{i, t}+\alpha_{5} D^{*} B V_{i, t}+\alpha_{6} C^{*} D^{*} B V_{i, t}+\alpha_{7} E_{i, t}+\alpha_{8} C^{*} E_{i, t}+\alpha_{9} D^{*} E_{i, t}+ \\
& \alpha_{10} C^{*} D^{*} E_{i, t}+\alpha_{11} E_{i, t}+\alpha_{12} C^{*} \Delta E_{i, t}+\alpha_{13} D^{*} \Delta E_{i, t}+\alpha_{14} C^{*} D^{*} \Delta E_{i, t}+\sum C V s+\varepsilon_{i, t}
\end{aligned}
$$

where $C$ is a legal origin dummy equal to 1 if a firm observation is from a common law country and 0 otherwise. $C^{*} B V_{i, t}, D^{*} B V_{i, t}$ and interactive $C^{*} D^{*} B V_{i, t}$ signify the incremental impact of common law origin on the book value of equity to the base case $\alpha_{3} B V_{i, t}$ before IFRS. Similarly, $C^{*} E_{i, t}, D^{*} E_{i, t}$ and $C^{*} D^{*} E_{i, t}$ and $C^{*} \Delta E_{i, t}, D^{*} \Delta E_{i, t}$ and $C^{*} D^{*} \Delta E_{i, t}$ measure the incremental effect of common law origin on earnings components. Panel regressions are then run that include year effects and firm specific controls but dropping country controls. Similarly, for rule-of-law:

$$
\begin{aligned}
& P_{i, t}=\alpha_{0}+\alpha_{1} D_{i, t}+\alpha_{2} R_{i, t}+\alpha_{3} B V_{i, t}+\alpha_{4} R^{*} B V_{i, t}+\alpha_{5} D^{*} B V_{i, t}+\alpha_{6} R^{*} D^{*} B V_{i, t}+\alpha_{7} E_{i, t}+\alpha_{8} R^{*} E_{i, t}+\alpha_{9} D^{*} E_{i, t}+ \\
& \alpha_{10} R^{*} D^{*} E_{i, t}+\alpha_{11} \Delta E_{i, t}+\alpha_{12} R^{*} \Delta E_{i, t}+\alpha_{13} D^{*} \Delta E_{i, t}+\alpha_{14} R^{*} D^{*} \Delta E_{i, t}+\sum C V s+\varepsilon_{i, t}
\end{aligned}
$$

where $\mathrm{R}$ is a rule-of-law dummy which equals 1 if the rule-of-law (P-rank) value, obtained from the Kaufman Governance Database, is greater than the median value over the research period, and 0 otherwise. Incremental and control variables are as previously defined.

\section{Secrecy Culture}

To assess the impact of secrecy culture on the value relevance of IFRS, we apply the secrecy index-countries with high levels of power distance and uncertainty avoidance and lower levels of individualism are more likely to have a secretive culture. The secrecy $(S)$ variable model, along with year and firm controls, is as follows:

$$
\begin{aligned}
& P_{i, t}=\alpha_{0}+\alpha_{1} D_{i, t}+\alpha_{2} S_{i, t}+\alpha_{3} B V_{i, t}+\alpha_{4} S * B V_{i, t}+\alpha_{5} D^{*} B V_{i, t}+\alpha_{6} S * D^{*} B V_{i, t}+\alpha_{7} E_{i, t}+\alpha_{8} S * E_{i, t}+ \\
& \alpha_{9} D^{*} E_{i, t}+\alpha_{10} S * D^{*} E_{i, t}+\alpha_{11} \Delta E_{i, t}+\alpha_{12} S * \Delta E_{i, t}+\alpha_{13} D^{*} \Delta E_{i, t}+\alpha_{14} S * D^{*} \Delta E_{i, t}+\sum C V s+\varepsilon_{i, t}
\end{aligned}
$$

where $S$ denotes a secretive country if the secrecy index is greater than the median value determined following the method of Hope et al. (2008). Table 4 sets out the interactions between variables in order to assist in the interpretation of the multivariate results by identifying the combinations of coefficients that need to be considered to assess the significance of any particular combination of variables. In Table 4, the base case constitutes the group of country firms pre IFRS and classified as non-secretive. 


\section{INSERT TABLE 4 ABOUT HERE}

\section{Results}

\subsection{The ERC and BRC Coefficients}

Table 5 reports the aggregated country results for the ERC and BRC after applying the several variants of equation (1). The coefficients of major interest are the IFRS dummy coefficients. First addressing earnings, there is only one significant coefficient for the change in earnings component [M4: $0.259(\mathrm{t}=1.76)]$ after IFRS. Another approach is to add all earnings coefficients together to derive an $8.7 \%$ increase (from 0.753 to 0.819$)^{8}$ indicating a small but insignificant incremental increase after IFRS. ${ }^{9}$ Whilst noting that all ERC levels coefficients are stable and highly significant pre IFRS [e.g. M4: $0.826(t=9.16)]$, the best we can conclude is that aggregate earnings continue to be price relevant, but IFRS adds little. These results are consistent with the no-change earnings hypothesis of Horton et al. (2013) and Prather-Kinsey (2006) who reported an ERC decrease by $76.6 \%$ after convergence of South African accounting standards to IFRS. A check on the decomposed South African data also provided similar insignificant changes after IFRS.

Turning to net book values a different story emerges. Table 5 shows that after IFRS the BRC dummy coefficients are positive and statistically significant at the $5 \%$ level. For example, in Model 4 the adjusted coefficient increased from 0.041 to 0.135 , representing an increase of 229\%. This shows that after IFRS there was greater alignment of the book value of equity closer to share prices-more likely due to the incorporation of contemporary measurement principles for assets and liabilities. These initial cross-sectional findings support the IASB stance of a primary focus on the statement of financial position as the driver of incremental value relevance under IFRS. Results are also consistent with PratherKinsey (2006) who reports an aggregate equity book value response coefficient of 0.539 for South African firms, representing an increase of $158.1 \%$ over pre IFRS levels. ${ }^{10}$ Finally, in all separate sample and dummy variable regressions there are increases in adjusted $\mathrm{R}^{2}$. This somewhat supports an overall joint value relevance of earnings and net book value of equity

\footnotetext{
${ }^{8}[(0.826-0.073)]=[(0.753+(-0.193+0.259)]=0.819]$

${ }^{9}$ We also ran this model after dropping banks and financial firms. Base BRC and ERC's were similar in direction and size but the IFRS dummy showed a slightly higher impact on earnings coefficients at weak significant levels.

${ }^{10}$ Running a separate regression on South African data we find a $41.8 \%$ increase in the BRC after IFRS.
} 
for prices, but again it is the net book value of equity which has the more powerful incremental value relevant information content after IFRS.

\section{INSERT TABLE 5 ABOUT HERE}

\subsection{The Impact of Legal Proxies}

Table 6 Panel A reports results on the impact of legal origin on the ERC and BRC, split into common law countries (South Africa, Botswana and Kenya) and code law countries (Egypt and Morocco). Results are confined to the full model using panel regressions with year and firm controls, along with interactive dummy variables (D) for IFRS and (C) that tests for incremental value relevance for common law countries. We repeat this approach using a dummy variable $(\mathrm{R})$ for countries with rule-of-law greater than the median value (South Africa and Botswana) from the Kaufman Governance Database.

First focusing on all coefficients that contain the interactive dummy (D) representing changes after IFRS, there are no significant impacts, except for earnings level after IFRS for weak rule-of-law countries [R*D*E: $0.881(\mathrm{t}=1.857)]$. We also have an interest in the importance of legal foundations on accounting which is captured by the (C) and (R) dummies. Pre IFRS for the BRC there is no significant value relevance difference between code and common law [C*BV: $0.027(\mathrm{t}=0.585)]$, nor for rule-of-law [R*BV: 0.007 $(\mathrm{t}=0.164)]$. Similarly for the ERC (levels), there is no difference pre IFRS but as noted above a positive impact after IFRS for strong rule-of-law countries. Finally, for the ERC (change) variable there are significant positive price associations pre IFRS for common law and strong rule-of-law countries, with no significant changes after IFRS. In summary, the results are not strong. The legal classifications of code/common law and rule-of-law do not reveal any major impacts after IFRS, with the caveat that post IFRS ERC coefficient for countries with strong rule-of-law increased. These results suggest that any IFRS change explanation may lay elsewhere and we now turn to consideration of the secrecy index.

\subsection{The Impact of a Secrecy Culture}

We introduce $S$ as a dummy variable equal to 1 if the secrecy value is greater than the Hofstede international median value of 91, and 0 otherwise. Botswana was dropped because 
it is not included in Hofstede cultural dimensions, ${ }^{11}$ resulting in three countries above the secrecy median score (Kenya, Egypt and Morocco) and South Africa below the median score. $^{12}$ Results show that the value relevance of the BRC increased after IFRS for South Africa [D*BV: $0.116(\mathrm{t}=2.392)]$, and also for secrecy countries [S*D*BV: 0.422 $(t=1.659)]$ - from the same base of $0.058 .^{13}$ For the ERC's, pre IFRS they are more value relevant in secrecy societies [S*E: $\left.1.259(\mathrm{t}=3.274), \mathrm{S}^{*} \Delta \mathrm{E}: 2.256(\mathrm{t}=1.841)\right]$ and the ERC levels component [S*D*E: $1.989(\mathrm{t}=2.011)]$ increases further after IFRS. That is in secrecy societies, accounting and earnings in particular, are significantly important in determining value both before and after IFRS.

To summarise, in African countries with secrecy cultures (and Botswana), accounting earnings play an important incremental role in providing value relevant information to stock markets-and more so compared to the less secretive South African market. It is also interesting to observe the impact of IFRS on the differential accounting components. In secretive cultures the increased impact comes through earnings from an already high base, whilst in South Africa the marginal impact is through the balance sheet. At first pass the result may not seem intuitive. However, if asset markets in secretive cultures are opaque and illiquid, then there is little reason that net asset re-measurements required under the three IFRS valuation tiers would provide a good deal of value relevance. ${ }^{14}$ Hence, the default accounting valuation component naturally falls back on earnings, and in a secretive society, represents one of the restrictive channels of external reporting (and governance). In short, taking on heightened importance in secretive societies where there is a relative scarcity of formal value relevant information.

\section{INSERT TABLE 6 ABOUT HERE}

\subsection{Robustness Tests and Additional Analyses}

We check robustness by applying a number of alternative empirical tests including robust regressions, weighted least squares, and returns based regressions. Lev and Ohlson (1982)

\footnotetext{
11 The model was run separately for Botswana resulting in non-significance for the BRC both before and after IFRS. The ERC levels coefficient was 1.537 before IFRS and 5.472 afterwards. The ERC change was insignificant before and after IFRS. These results are in the same direction and levels as countries determined as secretive (see Table 6).

12 Based upon the Hofstede cultural dimensions we calculated secrecy scores of South Africa 33, Morocco 92, Kenya 95 and Egypt 110. The median score for all countries in Hofstede is 91, leaving South Africa as the only non-secretive country.

13 There was no significant difference between secrecy and the less secretive countries.

14 This would especially be the case if unreliable asset markets forced managers to revert to Tier 3 valuation methods.
} 
argue that accounting variables have information content only when they can produce qualitatively similar results in both price level and change models. Kothari and Zimmerman (1995) further suggest that the use of both price and returns models (whenever possible) to mitigate econometric problems. For instance, whilst price level models are less biased but suffer from heteroskedasticity, return models are less heteroskedastic but have more bias. The returns-based models report similar results. Also linear fixed and random effects regressions are used to control for unobservable heterogeneity effect, and one step GMM regressions are used to control for potential endogeneity between share prices and earnings. In addition, we exclude banks, apply Hope et al's. (2008) suggested winsorizing at 1\%, and a four month accounting reporting period to mitigate the financial accounting reporting lag effect. Results are quantitatively the same.

\section{Conclusions}

In this paper we examine the value relevance of accounting across several African countries and test whether IFRS improved the value association of earnings and equity book values. Motivation was provided by an inference that IFRS may not be suitable in Africa because, unlike developed economies, African capital markets are illiquid, price ineffectual, and have relatively weak enforcement mechanisms and regulatory environments (Ball 2008, Bova 2009). Initial aggregate results showed IFRS resulted in increased book response coefficients but only marginal increases in earnings response coefficients-consistent with PratherKinsey (2006), the IASB (2010) focus on the statement of financial position as the dominant accounting valuation metric, and European research (e.g. Hung and Subramanyam 2007, Schiebel 2007).

After decomposing using a secrecy index we find a stronger valuation association between earnings and stock prices in secretive African countries which increases after IFRS. The relative higher importance of earnings is likely explained by opaque and illiquid asset markets that gain little from the revaluation balance sheet focus of IFRS (Ball 2006). On the other hand, the book value coefficient had a stronger increase after IFRS in the less secretive and more developed South African market. In essence, accounting earnings as the default information cue, provided an external source of valuation information in secretive cultures. The legal based control variables of code/common law and rule-of-law showed little marginal explanatory power, supporting the contention that IFRS improvements in Africa are more related to cultural foundations. 
Our results are consistent with Barton et al's. (2010) thesis that investors around the world place different value relevance on earnings and book values according to individual country characteristics (see also Cascino and Gassen 2012), and that secrecy plays a strong role in accounting quality (Hope et al. 2008). We conjecture that the more conceptual focus of IFRS induced an increased demand for higher quality accounting professionals, and this has had a second order effect of improving managerial decision making (Albu et al. 2011). Accordingly, future research could profit from a greater concentration on a more microanalysis that drills down to individual country, firm and industry factors to forensically assess the accounting variables that are associated with capital market prices. Regardless, future research should consider the impact of secrecy as a cultural derivative as well as the more common legal controls. 


\section{References}

Akman, N.H. (2011).The Effect of IFRS Adoption on Financial Disclosure: Does Culture Still Play a Role? American International Journal of Contemporary Research, 1(1), 617.

Alali, F.A. and P.S. Foote. (2012). The Value Relevance of International Reporting Standards: Empirical Evidence in an Emerging Market, The International Journal of Accounting, 47(1), 85-108.

Albu, C., N. Albu, R. Faff, and A. Hodgson. (2011). The Changing Role of Accountants in a Transition Economy - Evidence from Romania, Accounting in Europe. 8(2), 155-184.

Anandarajan, A and I. Hasan. (2010). Value Relevance of Earnings: Evidence from Middle Eastern and North African Countries, Advances in Accounting, Incorporating Advances in International Accounting, 26(2), 270-279.

ASEA, (2011). African Securities Exchanges Association, available at http://www.africansea.org/asea/Default.aspx?AspxAutoDetectCookieSupport=1.

Aubert, F. and G. Grudnitski. (2011). The Impact and Importance of Mandatory Adoption of International Financial Reporting Standards in Europe, Journal of International Financial Management and Accounting, 22 (1), 1-26.

Ball, R. (2006). International Financial Reporting Standards (IFRS): Pros and Cons for Investors, Accounting and Business Research, International Accounting Policy Forum, pp. 5-27.

Ball, R. (2008). Do not Blame the Messenger or Ignore the Message, Skeptical CPA: Shoot the Messenger, Monday, November 10 available at http://skepticaltexascpa.blogspot.com/2008/11/shoot-messenger.html.

Ball, R, A. Robin and J.S. Wu. (2003). Incentives Versus Standards: Properties of Accounting Income in Four East Asian Countries and Implications for Acceptance of IAS. Journal of Accounting and Economics, 36 (1-3), 235-270.

Ball, R, S.P. Kothari, and A. Robin. (2000). The Effect of International Institutional Factors on Properties of Accounting Earnings, Journal of Accounting and Economics, 29 (1), $1-51$.

Barth, M.E. (2006). Including Estimates of the Future in Today's Financial Statements, Accounting Horizons, 20(3), 271-285.

Barth, M.E. (2007). Research, Standard Setting, and Global Financial Reporting, Hanover, MA: New Publishers.

Barth, M.E, W.R. Landsman and M.H. Lang. (2008). International Accounting Standards and Accounting Quality. Journal of Accounting Research, 46 (3), 467-498.

Barth, M.E, W.R. Landsman, M.H. Lang and C.D. Williams. (2012). Are IFRS-Based and US GAAP-Based Accounting Amounts Comparable? Journal of Accounting and Economics, 54(1), 68-93. 
Barton, J, T.B. Hansen and G. Pownall. (2010). Which Performance Measures Do Investors Around the World Value the Most and Why? The Accounting Review, 85 (3), 753789.

Bartov, E, S. Goldberg and M. Kim. (2005). Comparative Value Relevance among German, U.S., and International Accounting Standards: A German Stock Market Perspective, Journal of Accounting, Auditing and Finance, 20(2), 95-119.

Beckman, J, C. Brandes and B. Eierle. (2007). Analysis and Reconciliations from German Commercial Code to IFRS or US GAAP, Advances in International Accounting, 20, 253-294.

BIA, (2011).Botswana Institute of Accountants, now the Botswana Institute of Chartered Accountants, available at http://www.bia.org.bw/.

Bissessur, S. and A. Hodgson. (2012). Stock Market Synchronicity-An Alternative Approach to Assessing the Information Impact of Australian IFRS, Accounting and Finance, 52 (1), 187-212.

Bova, F. (2009). The Determinants and Consequences of Higher IFRS Compliance Following Mandatory IFRS Adoption in Weak Regulatory Regimes, Working Paper Series, Rotman School of Management, University of Toronto.

Bradshaw, M.T., M.S. Drake, J.N. Myers and L.A. Myers. (2012). A Re-examination of Analysts' Superiority over Time-series Forecasts of Annual Earnings, Review of Accounting Studies, 17, 944-968.

Brown, P. (2011). International Financial Reporting Standards: What are the Benefits? Accounting and Business Research, 41 (3), 269-285.

Brüggemann, U., J. M. Hitz and T. Sellhorn. (2013). Intended and Unintended Consequences of Mandatory IFRS Adoption: A Review of Extant Evidence and Suggestions for Future Research. European Accounting Review, 22(1), 1-37.

Cascino, S. and J. Gassen. (2012). Comparability Effects of Mandatory IFRS Adoption, SFB 649, Discussion Paper, 2012-009.

Chow, L., G.K., Chau and S.J. Gray. (1995). Accounting Reforms in China: Cultural Constraints on Implementation and Development, Accounting and Business Research, 26 (1), 29-49.

Dahawy, K., B.D. Merino and T.L. Conover. (2002). The Conflict between IAS Disclosure Requirements and the Secretive Culture in Egypt, Advances in International Accounting, 15(1), 202-228.

Dam,W. (2006). Legal Institutions, Legal Origins, and Governance, John. M. Olin Law Working Paper No. 303, ( $2^{\text {nd }}$ Series), Chicago.

Daske, H. and G. Gebhardt. (2006). International Financial Reporting Standards and Experts Perceptions of Disclosure Quality, Abacus, 42(3-4), 461-498. 
Daske, H. L., Hail, C. Leuz, and R. Verdi. (2008). Mandatory IFRS Reporting Around the World: Early Evidence on the Economic Consequences, Journal of Accounting Research, 46, 1085-1142.

DeFond, M., X. Hu, M. Hung, and S. Li. (2011). The Impact of Mandatory IFRS Adoption on Foreign Mutual Fund Ownership: The Role of Comparability, Journal of Accounting and Economics, 51, 240-258.

Deloitte, (2011). IFRS in Your Pocket: Use of IFRSs Around the World, Deloitte and Touché. Available at http://www.iasplus.com/dttpubs/pocket2011.pdf.

Ding, Y, T. Jean Jean, and H. Stolowy. (2005). Why Do National GAAP Differ From IAS? The Role of Culture, The International Journal of Accounting, 40 (4), 325-350.

Ding, Y, T. Jean Jean, and H. Stolowy. (2009). Observations on Measuring the Differences between Domestic Accounting Standards and IAS: A Reply, Journal of Accounting and Public Policy, 28(2) 154-161.

Doupnik, T.S. and G.T. Tsakumis. (2004). A Critical Review of Tests of Gray's Theory of Cultural Relevance and Suggestions for Future Research, Journal of Accounting Literature, 23, 1-48.

Dye, R.A and S.S. Sridhar. (2004). Reliability-Relevance Trade-offs and the Efficiency of Aggregation, Journal of Accounting Research, 42(1), 51-88.

Eccher, E. and P.M. Healy. (2003). The Role of International Accounting Standards in Transitional Economies: A Study of the People's Republic of China, Working Paper, Massachusetts Institute of Technology, Available at SSRN: http://papers.ssrn.com/paper.taf?abstract_id=233598.

EStandards Forum. (2010). Standards Compliance Index and Business Indicators Index: Individual Countries' Information, available at http://www.estandardsforum.com.

European Union. (2002). Regulation (EC) No 1606/2002 of the European Parliament and of the Council of 19 July 2002 on the Application of International Accounting Standards. Official Journal of the European Communities, L 243: 1-4.

FASB. (2010). Financial Accounting Standards Board, The Conceptual Framework on Objectives and Qualitative Characteristics issued jointly by the IASB and FASB on $28^{\text {th }}$ September 2010.

Florou, A and P.F. Pope. (2012). Mandatory IFRS Adoption and Institutional Investment Decisions, The Accounting Review, 87(6), 1993-2025.

Foster, G. (1977). Quarterly Accounting Data: Time-series Properties and Predictive Ability Results. The Accounting Review, 52: 1-21.

Francis, J. and K. Schipper. (1999). Have Financial Statements Lost Their Relevance? Journal of Accounting Research, 37 (2), 319-352.

Gray, S.J. (1988). Towards a Theory of Cultural Influence on the Development of Accounting Systems Internationally, Abacus, 24 (1), 1-15. 
Gray, S.J and H.M. Vint. (1995). The Impact of Culture on Accounting Disclosure: Some International Evidence, Asia-Pacific Journal of Accounting, 2 (1), 33-43.

He, X, T.J. Wong and D. Young. (2012). Challenges for Implementation of Fair Value Accounting in Emerging Markets: Evidence from China, Contemporary Accounting Research, 29 (2), 538-562.

Hofstede, G. (1980). Culture's Consequences: International Differences in Work-Related Values, Integral Edition, Beverly Hills, CA, Sage.

Hofstede, G. (2001). Culture's Consequences: Comparing Values, Behaviours, Institutions, and Organizations Across Nations, Second Edition, London, Sage Publications.

Hope, O.K. (2003a). Disclosure Practices, Enforcement of Accounting Standards, and Analysts' Forecast Accuracy: An International Study, and the Relative Roles of Culture and Legal Origin, Journal of Accounting Research, 41, 2, 235-272.

Hope, O.K. (2003b). Firm Level Disclosures and the Relative Roles of Culture and Legal Origin, Journal of International Financial Management and Accounting, 14(3), 218248.

Hope, O.K, T. Kang, W. Thomas, and Y.K. Yoo. (2008). Culture and Auditor Choice: A Test of the Secrecy Hypothesis, Journal of Accounting and Public Policy, 27 (5), 357-373.

Horton, J., G. Serafein, and I. Serafein, (2013). Does Mandatory IFRS Adoption Improve the Information Environment? Contemporary Accounting Research, 30, 1 (Spring 2013), 388-423.

Hung, M, and K. Subramanyam. (2007). Financial Statement Effects of Adopting International Accounting Standards: The Case of Germany, Review of Accounting Studies, 12 (4), 21-48.

IASB. (2010). International Accounting Standards Board: The Conceptual Framework on Objectives and Qualitative Characteristics issued jointly by the IASB and FASB on $28^{\text {th }}$ September 2010.

Jaggi, B, and P.Y. Low. (2000). Impact of Culture, Market Forces, and Legal System on Financial Disclosures, The International Journal of Accounting, 35 (4), 495-519.

Jermakowicz, E.K, J.J. Prather-Kinsey and I. Wulf. (2007). The Value Relevance of Accounting Income Reported by DAX-30 German Companies, Journal of International Financial Management and Accounting, 18 (3), 151-191.

Kenny, C.J. and T.J. Moss. (1998). Stock Markets in Africa: Emerging Lions or White Elephants? World Development, 26(5), 829-843.

Kothari, S.P. (2001). Capital Markets Research in Accounting, Journal of Accounting and Economics, 31(1-3), 105-231.

Kothari, S.P. (1992). Price-Earnings Regressions in the Presence of Leading Earnings: Earnings Level versus Change Specifications and Alternative Deflators, Journal of Accounting and Economics, 15 (2-3), 173-202. 
Kothari, S.P. and R. Sloan. (1992). Information in Prices about Future Earnings: Implications for Earnings Response Coefficients, Journal of Accounting and Economics, 15(2-3), 143-171.

Kothari, S.P. and J.L. Zimmerman. (1995). Price and Return Models, Journal of Accounting and Economics, 20 (2), 155-192.

La Porta, R, F. Lopez-de-Silanes, and A. Shleifer. (1999). Corporate Ownership Around the World, Journal of Finance, 54 (2), 471-517.

La Porta. R, F. Lopez-de-Silanes, A. Shleifer and R.W. Vishny. (1998). Law and Finance, Journal of Political Economy, 106 (6), 1113-1155.

Lantto, A. (2007). Does IFRS Improve the Usefulness of Accounting Information in a CodeLaw Country? Working Paper, Department of Accounting and Finance, University of Oulu, Finland.

Lev, B. (1989). On the Usefulness of Earnings and Earnings Research: Lessons and Directions from two Decades of Empirical Research, Journal of Accounting Research, 27(3), 153-192.

Lev, B. and J.A. Ohlson. (1982). Market-Based Empirical Research in Accounting: A Review, Interpretation and Extension, Journal of Accounting Research, 20 (Supplement), 249-322.

Li, S. (2010). Does Mandatory Adoption of International Accounting Standards Reduce the Cost of Equity Capital? The Accounting Review, 85, 607-636.

Lin, Z.J and F. Chen. (2005). Value Relevance of International Accounting Standards Harmonization: Evidence from A- and B-share markets in China, Journal of International Accounting, Auditing and Taxation, 14 (2), 79-103.

Liu, J and C. Liu. (2007). Value Relevance of Accounting Information in Different Stock Market Segments: The Case of Chinese A-, B-, and H-Shares, Journal of International Accounting Research, 6(2), 55-81.

Lorek, K.S. and D.P. Pagach. (2014). Analysts versus Time-Series Forecasts of Quarterly Earnings: A Maintained Hypothesis Revisited, Working Paper, Poole College of Management, NC State, North Carolina.

Negash, M. (2008). Liberalization and the Value Relevance of Accrual Accounting Information: Evidence from the Johannesburg Securities Exchange, Afro-Asian Journal of Finance and Accounting, 1(1), 81-104.

Ohlson, J.A. (1995). Earnings, Book Values and Dividends in Equity Valuation, Contemporary Accounting Research, 11(2), 661-687.

Ohlson, J.A. (2009). Accounting Data and Value: The Basic Results, Contemporary Accounting Research, 26(1), 231-259.

Ohlson, J.A. and B.E. Juettner-Nauroth. (2004). Expected EPS and EPS Growth as Determinants of Value, Review of Accounting Studies, 10(2-3), 349-365. 
Papadaki, A. (2005). Discussion of "Why Do National GAAP Differ from IAS? The Role of Culture,” The International Journal of Accounting, 40 (4), 351-358.

Penman, S. and N. Yehuda. 2015. A Matter of Principle: Accounting Reports Convey Both Cash-Flow News and Discount-Rate News, Working Paper, Columbia University, January.

Piotroski, J.D. (2000). Value Investing: The Use of Historical Financial Statement Information to Separate Winners from Losers, Journal of Accounting Research, 38, 141.

Piotroski, J.D. and E.C. So. (2012). Identifying Expectation Errors in Value/Glamour Strategies: A Fundamental Analysis Approach, Review of Financial Studies, 25 (9), 2841-2875.

Pope, P.F. and S. McLeay. (2011). The European IFRS Experiment: Objectives, Research Challenges and Some Early Evidence, Accounting and Business Research, 41 (3), 233-266.

Preiato, J., P. Brown and A. Tarca. (2014). Comparison of Between-Country Measures of Legal Setting and Enforcement of Accounting Standards, Working Paper, Business School, University of Western Australia, April.

Prather-Kinsey, J. (2006). Developing Countries Converging with Developed-Country Accounting Standards: Evidence from South Africa and Mexico, The International Journal of Accounting, 41 (2), 141-162.

Risberg, M. (2005). Corporate Governance and Accounting Quality: Is Bad News Good

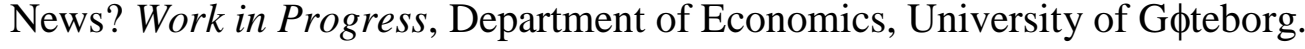

Schipper, K. (2005). The Introduction of International Accounting Standards in Europe: Implications for International Convergence, European Accounting Review, 14(1), 101-126.

Shan, Y., S. Taylor and T. Walter. (2014). The Role of “Other Information” in Analysts' Forecasts in Understanding Stock Return Volatility, The Review of Accounting Studies, 19(4). 1346-1392.

Smith, G.,K. Jefferis and H. Ryoo. (2002). African Stock Markets: Multiple Variance Ratio Tests of Random Walks, Applied Financial Economics, 12(7), 475-484.

Stulz, R.M. and R. Williamson. (2003). Culture, Openness, and Finance, Journal of Financial Economics, 70(3), 313-349.

Tsalavoutas, I., P. Andrè and L. Evans. (2010). The Transition to IFRS and the Value Relevance of Financial Statements in Greece, British Accounting Review, 44(4), 262277.

Verma, S and S. Gray. (1998). The impact of Culture on Accounting Development and Change: An Exploratory Framework, London, Birckbeck Coll.

Zimmerman, J. L. (2013). Myth: External Financial Reporting Quality has a First-order Effect on Firm Value. Accounting Horizons, 27(4), 887-894. 
Walker, M. (2010). Accounting for Varieties of Capitalism: The Case against a Single Set of Global Accounting Standards, The British Accounting Review, 42 (3), 137-152.

World Bank, (2001). A Report on the Observance of Standards and Codes (ROSC) on Republic of Kenya. Accounting and Auditing, available at http://www.worldbank.org/ifa/rosc_aa.html.

World Bank, (2006). A Report on the Observance of Standards and Codes (ROSC) on Republic of Botswana, Accounting and Auditing, http://www.worldbank.org/ifa/rosc_aa.html.

World Bank, (2010a). A Report on the Observance of Standards and Codes (ROSC) on Morocco, Egypt and Kenya, Accounting and Auditing, http://www.worldbank.org/ifa/rosc_aa.html.

World Bank, (2010b). World Bank Exchange Rates and Currencies, available at http://dataworldbank.org/exchangeratesandcurrencies. 
Table 1 -Firms by Country and Industry Distribution

\begin{tabular}{|c|c|c|c|c|c|c|c|}
\hline \multirow[t]{2}{*}{ No } & \multirow[t]{2}{*}{ Industry } & \multicolumn{5}{|c|}{ Number of Firms } & \multirow[b]{2}{*}{ Total } \\
\hline & & Kenya & $\begin{array}{l}\text { South } \\
\text { Africa }\end{array}$ & Morocco & Egypt & Botswana & \\
\hline 1 & Mining & 1 & 24 & 2 & 0 & 0 & 27 \\
\hline 2 & Oil and Gas & 0 & 3 & 2 & 1 & 1 & 7 \\
\hline 3 & Construction & 1 & 5 & 4 & 5 & 0 & 15 \\
\hline 4 & Banking & 6 & 9 & 5 & 9 & 4 & 33 \\
\hline 5 & Insurance & 2 & 3 & 1 & 0 & 1 & 7 \\
\hline 6 & Financial services & 2 & 15 & 3 & 3 & 4 & 27 \\
\hline 7 & Beverages & 1 & 2 & 1 & 0 & 1 & 5 \\
\hline 8 & Transportation & 1 & 1 & 0 & 0 & 0 & 2 \\
\hline 9 & Utilities & 1 & 1 & 0 & 0 & 0 & 2 \\
\hline 10 & Agriculture & 3 & 6 & 0 & 2 & 0 & 11 \\
\hline 11 & Communications and Logistics & 2 & 12 & 0 & 3 & 0 & 17 \\
\hline 12 & Health Care & 0 & 3 & 0 & 1 & 1 & 5 \\
\hline 13 & Hotel and Tourism & 1 & 8 & 1 & 3 & 1 & 14 \\
\hline 14 & Motorcar and Tyres & 2 & 1 & 0 & 0 & 0 & 3 \\
\hline 15 & Manufacturing and Distribution & 1 & 88 & 5 & 13 & 1 & 108 \\
\hline \multirow[t]{2}{*}{16} & Others & 0 & 61 & 0 & 0 & 3 & 64 \\
\hline & Total & 24 & 242 & 24 & 40 & 17 & 347 \\
\hline
\end{tabular}

Note: Non-financial firms comprise $81 \%$ and financial firms comprise $19 \%$ of the sample. Financial firms include banks, insurance and financial services. 
Table 2 - Descriptive Statistics for the Pooled Data (\$US currency)

\begin{tabular}{|c|c|c|c|c|c|c|c|c|c|c|c|c|c|c|c|}
\hline \multicolumn{5}{|c|}{ Whole Sample } & \multicolumn{4}{|l|}{ Pre IFRS } & \multicolumn{4}{|c|}{ Post IFRS } & \multicolumn{3}{|c|}{ Paired t test (pre and post IFRS) } \\
\hline Variable & $\mathbf{N}$ & $\mu$ & $\rho 50$ & $\delta$ & $\mathbf{N}$ & $\mu$ & $\rho 50$ & $\delta$ & $\mathbf{N}$ & $\mu$ & $\rho 50$ & $\delta$ & Mean diff. & t-stat diff $=0$ & $\begin{array}{l}\mathbf{p}>\mid \mathbf{t} \\
\mid\end{array}$ \\
\hline$E P S_{i, t}$ & 2776 & 4.07 & 0.10 & 14.40 & 1130 & 1.58 & 0.12 & 5.56 & 1646 & 6.55 & 0.09 & 23.20 & -4.97 & $-6.91 *$ & 0.000 \\
\hline$\triangle E P S_{i, t}$ & 2776 & 0.43 & 0.00 & 8.86 & 1130 & 0.20 & 0.02 & 4.02 & 1646 & 0.65 & 0.01 & 13.70 & -0.45 & -0.87 & 0.382 \\
\hline$B V P S_{i, t}$ & 2776 & 18.98 & 0.70 & 92.40 & 1130 & 10.47 & 0.58 & 70.54 & 1646 & 27.49 & 0.49 & 114.20 & -17.02 & $-6.32 *$ & 0.000 \\
\hline$P_{i, t}$ & 2776 & 19.14 & 1.25 & 65.30 & 1130 & 21.73 & 0.82 & 69.40 & 1646 & 16.55 & 1.67 & 61.30 & 5.18 & $7.05^{*}$ & 0.000 \\
\hline SIZE & 2776 & 7.98 & 7.67 & 3.41 & 1130 & 7.64 & 7.41 & 3.34 & 1646 & 8.31 & 7.93 & 3.50 & -0.67 & $-10.32 *$ & 0.000 \\
\hline$L E V$ & 2776 & 2.45 & 1.10 & 3.49 & 1130 & 2.63 & 1.08 & 2.84 & 1646 & 2.27 & 1.12 & 4.14 & 0.36 & $3.21 *$ & 0.001 \\
\hline GROWTH & 2776 & -0.09 & 0.05 & 5.35 & 1130 & -0.30 & 0.05 & 10.19 & 1646 & 0.12 & 0.07 & 0.50 & -0.42 & -1.07 & 0.284 \\
\hline
\end{tabular}

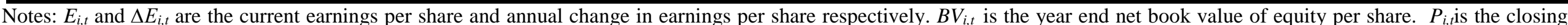

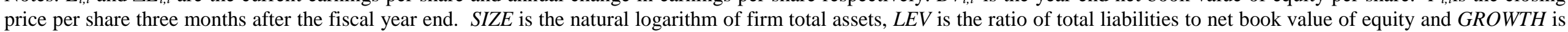
defined as the change in revenue divided by total assets. ***, ** and * denote statistical significance at $1 \%$, $5 \%$ and $10 \%$ using a two tailed t-tests. 
Table 3 - Pairwise Correlations

\begin{tabular}{|c|c|c|c|c|c|c|c|}
\hline & $E_{i, t}$ & $\Delta \boldsymbol{E}_{i, t}$ & $B V_{i, t}$ & $P_{i, t}$ & SIZE & $L E V$ & GROWTH \\
\hline$E_{i, t}$ & 1 & & & & & & \\
\hline$\Delta \boldsymbol{E}_{i, t}$ & $0.329 * *$ & 1 & & & & & \\
\hline$B V_{i, t}$ & $0.265^{* *}$ & $-0.079 * *$ & 1 & & & & \\
\hline $\boldsymbol{P}_{i, t}$ & $0.809 * *$ & $0.116^{* *}$ & $0.223^{* *}$ & 1 & & & \\
\hline SIZE & $0.178 *$ & 0.023 & $0.061^{*}$ & $0.186^{*}$ & 1 & & \\
\hline$L E V$ & -0.036 & -0.015 & -0.02 & -0.033 & $-0.046 * *$ & 1 & \\
\hline GROWTH & 0.011 & 0.002 & 0.006 & 0.011 & $0.066 * *$ & 0.003 & 1 \\
\hline
\end{tabular}

Notes: $E_{i, t}$ and $\Delta E_{i, t}$ are the current earnings per share and annual change in earnings per share respectively. $B V_{i, t}$ is the year end net book value of equity per share. $P_{i, t}$ is the closing price per share three months after the fiscal year end. SIZE is the natural logarithm of firm total assets, $L E V$ is the ratio of total liabilities to net book value of equity and GROWTH is defined as the change in revenue divided by total assets. 
Table 4: Example of Coefficients Applying a Secrecy Model

\begin{tabular}{|l|c|c|c|c|}
\hline \multirow{2}{*}{ Variable } & \multicolumn{2}{|c|}{ Post IFRS } & Pre IFRS \\
\hline & Secrecy & Non-Secrecy & Secrecy & $a_{7}+a_{8} S$ \\
\hline Earnings & $a_{7}+a_{9} D+a_{10} S^{*} D$ & $a_{7}+a_{9} D$ & $a_{11}+a_{12} S$ & $a_{7} *$ \\
\hline Change in Earnings & $a_{11}+a_{13} D+a_{14} S^{*} D$ & $a_{11}+a_{13} D$ & $a_{11}$ \\
\hline Net Book & $a_{3}+a_{5} D+a_{6} S^{*} D$ & $a_{3}+a_{5} D$ & $a_{3}+a_{4} S$ & $a_{3}^{*}$ \\
\hline
\end{tabular}

Notes: This table provides a coefficient characterisation of the full multivariate association model for countries with secretive cultures:

$P_{i, t}=\alpha_{0}+\alpha_{1} D_{i, t}+\alpha_{2} S_{i, t}+\alpha_{3} B V_{i, t}+\alpha_{4} S * B V_{i, t}+\alpha_{5} D * B V_{i, t}+\alpha_{6} S * D * B V_{i, t}+\alpha_{7} E_{i, t}+\alpha_{8} S * E_{i, t}+$

$\alpha_{9} D^{*} E_{i, t}+\alpha_{10} S * D * E_{i, t}+\alpha_{11} \Delta E_{i, t}+\alpha_{12} S * \Delta E_{i, t}+\alpha_{13} D * \Delta E_{i, t}+\alpha_{14} S * D * \Delta E_{i, t}+\sum C V s+\varepsilon_{i, t}$

The base case* represents a situation of pre IFRS/non-secrecy. 
Table 5 - The Aggregate Value Relevance Impact of IFRS Adoption on the ERC and BRC

\begin{tabular}{|c|c|c|c|c|c|c|c|c|c|c|c|c|c|}
\hline Dep.Var. & $\alpha_{0}$ & $D_{i, t}$ & $B V_{i, t}$ & $D^{*} B V_{i, t}$ & $E_{i, t}$ & $D^{*} E_{i, t}$ & $\Delta E_{i, t}$ & $D^{*} \Delta E_{i, t}$ & $A d R^{2}$ & $N$ & $F C V s$ & Year & Country \\
\hline \multirow[t]{2}{*}{$M 1: P_{i, t}$} & $0.963 * * *$ & & $0.048 * * *$ & & $0.720 * * *$ & & 0.012 & & 24.1 & 2776 & No & Yes & Yes \\
\hline & (19.587) & & (3.203) & & (9.659) & & $(0.162)$ & & & & & & \\
\hline \multirow[t]{2}{*}{$M 2: P_{i, t}$} & $0.903^{* * *}$ & $-0.211^{* *}$ & 0.027 & $0.083^{* *} *$ & $0.770 * * *$ & -0.244 & -0.02 & 0.209 & 24.5 & 2776 & No & Yes & Yes \\
\hline & $(10.375)$ & $(-2.309)$ & (1.495) & $(2.178)$ & (8.709) & $(-1.299)$ & $(-0.242)$ & (1.395) & & & & & \\
\hline \multirow[t]{2}{*}{$M 3: P_{i, t}$} & $0.917 * * *$ & & $0.063 * * *$ & & $0.791^{* * *}$ & & -0.023 & & 25.9 & 2776 & Yes & Yes & Yes \\
\hline & $(13.793)$ & & $(4.097)$ & & (10.154) & & $(-0.303)$ & & & & & & \\
\hline \multirow[t]{2}{*}{$M 4: P_{i, t}$} & $0.807 * * *$ & $-0.177^{* *}$ & $0.041 * *$ & $0.094 * *$ & $0.826 * * *$ & -0.193 & $\begin{array}{l}-0.073 \\
\end{array}$ & 0.259* & 26.4 & 2776 & Yes & Yes & Yes \\
\hline & (7.985) & $(-1.986)$ & $(2.192)$ & $(2.502)$ & (9.159) & $(-1.064)$ & $(-0.876)$ & (1.758) & & & & & \\
\hline
\end{tabular}

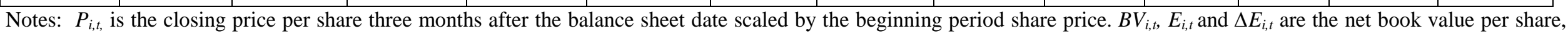

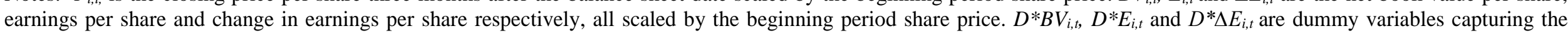

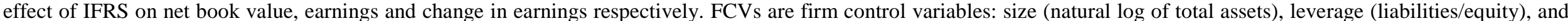

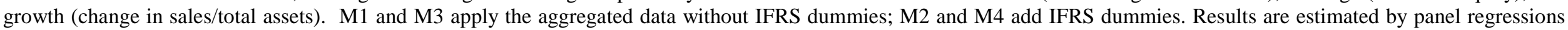
with robust t-statistics reported in parentheses. $* * *, * *$ and $*$ denote statistical significance at $1 \%, 5 \%$ and $10 \%$ using a two tailed t-tests. 
Table 6 - The Impact of Law and Secrecy on the Value Relevance of IFRS

Panel A- Legal Origin

\begin{tabular}{|c|c|c|c|c|c|c|c|c|c|c|c|c|c|c|c|c|}
\hline Dep. Var & $\alpha_{0}$ & $D$ & C & $B V$ & $C * B V$ & $D * B V$ & $C * D^{*} B V$ & E & $C^{*} E$ & $D^{*} E$ & $C^{*} D^{*} E$ & $\Delta E$ & $C^{*} \Delta E$ & $D^{*} \Delta E$ & $C^{*} D^{*} \Delta E$ & $A d R^{2}$ \\
\hline$P_{i, t}$ & $0.836^{* * *}$ & -0.130 & 0.159 & 0.002 & 0.027 & 0.103 & -0.040 & $1.010^{* * *}$ & -0.179 & -0.335 & 0.211 & $-0.436^{* * *}$ & $0.354^{* * *}$ & -0.012 & -0.021 & 25.2 \\
\hline 2776 obs. & (6.377) & (1.450) & (1.538) & $(0.051)$ & (0.585) & (1.251) & $(0.491)$ & (5.613) & (0.929) & (0.889) & $(0.551)$ & (4.045) & (3.363) & $(0.072)$ & (0.327) & \\
\hline
\end{tabular}

Panel B- Rule-of-Law

\begin{tabular}{|c|c|c|c|c|c|c|c|c|c|c|c|c|c|c|c|c|}
\hline Dep. Var & $\alpha_{0}$ & $D$ & $R$ & $B V$ & $R * B V$ & $D^{*} B V$ & $R * D^{*} B V$ & E & $R^{*} E$ & $D^{*} E$ & $R * D^{*} E$ & $\Delta E$ & $R^{*} \Delta E$ & $D^{*} \Delta E$ & $R^{*} D^{*} \Delta E$ & $A d R^{2}$ \\
\hline$P_{i, t}$ & $1.068^{* * *}$ & $0.299 * * *$ & $-0.098 * *$ & 0.036 & 0.007 & 0.031 & 0.078 & $0.789 * * *$ & -0.151 & -0.320 & $0.881^{*}$ & $-0.195^{* *}$ & $0.687^{* *}$ & 0.113 & -0.705 & 25.7 \\
\hline 2776 obs. & (10.343) & $(2.678)$ & (2.415) & $(1.642)$ & $(0.164)$ & $(0.692)$ & $(0.964)$ & (7.672) & $(0.612)$ & (1.565) & (1.857) & (1.980) & $(2.537)$ & $(0.850)$ & (1.134) & \\
\hline
\end{tabular}

\section{Panel C-Secretive Culture}

\begin{tabular}{|c|c|c|c|c|c|c|c|c|c|c|c|c|c|c|c|c|}
\hline Dep. Var & $\alpha_{0}$ & $D$ & $S$ & $B V$ & $S * B V$ & $D^{*} B V$ & $S^{*} D^{*} B V$ & E & $S^{*} E$ & $D^{*} E$ & $S^{*} D^{*} E$ & $\Delta E$ & $S^{*} \Delta E$ & $D^{*} \Delta E$ & $S^{*} D^{*} \Delta E$ & $A d R^{2}$ \\
\hline$P_{i, t}$ & $1.038^{* * *}$ & $0.450 * * *$ & $0.187^{* * *}$ & $0.058^{* * *}$ & -0.060 & $0.116^{* *}$ & $0.422 *$ & $0.612 * * *$ & $1.259 * * *$ & 0.296 & $1.989 * *$ & $-0.130^{*}$ & $2.256^{*}$ & 0.221 & -7.371 & 27.2 \\
\hline 2640 obs. & (20.657) & (5.229) & (3.057) & (3.097) & $(0.647)$ & (2.392) & (1.659) & (7.125) & (3.274) & (1.024) & (2.011) & (1.956) & (1.841) & $(0.734)$ & $(0.805)$ & \\
\hline
\end{tabular}

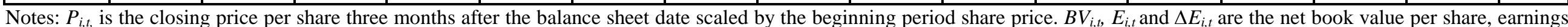

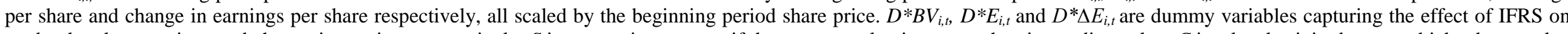

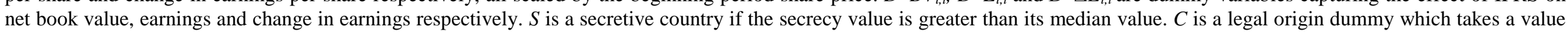

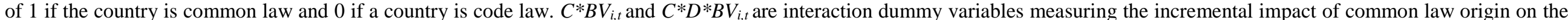

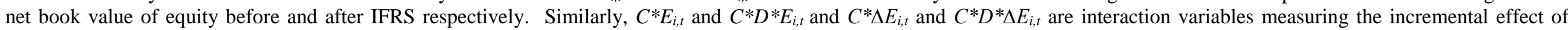

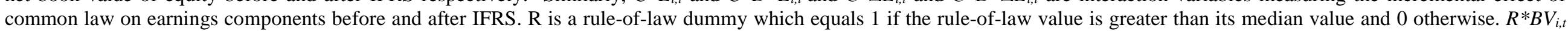

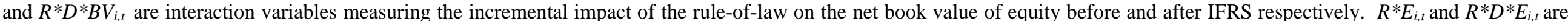

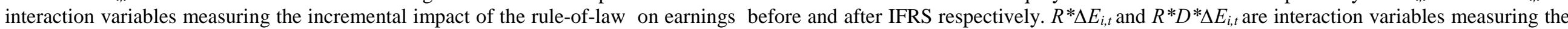

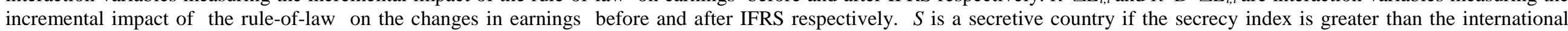

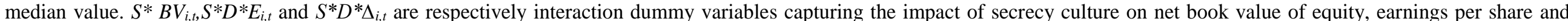

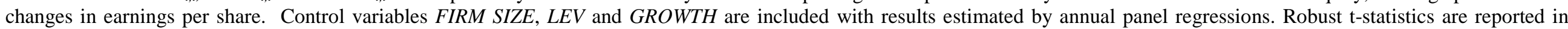
parentheses. $* * *, * *$ and $*$ denote statistical significance at $1 \%, 5 \%$ and $10 \%$ using a two tailed t-tests. 
Appendix 1: IFRS Adoption in Africa

\begin{tabular}{|c|c|c|c|c|}
\hline Country & Listed Companies & Unlisted Companies & Stock Market and Year Established & Adoption \\
\hline Botswana & Required for all domestic companies & Required for some and permitted for others & Botswana Stock Exchange (1989) & May2006 \\
\hline Gambia & No Capital Market & IFRS permitted & NA & \\
\hline Ghana & Required for all domestic companies & $\begin{array}{l}\text { Required for banks, utilities, brokerage, insurance, } \\
\text { government companies from 2007, others } 2009\end{array}$ & Ghana Stock Exchange (1990) & Jan2007 \\
\hline Egypt & Required for all domestic companies & Not permitted & Cairo \& Alexandria S E (1883) & 2005 \\
\hline Kenya & Required for all domestic companies & IFRS required for all & Nairobi Stock Exchange (1954) & 2005 \\
\hline Lesotho & IFRS permitted & Not permitted & NA & \\
\hline Libya & Neither required nor permitted & Required for commercial banks & Libyan Stock Exchange (2007) & \\
\hline Madagascar & No Capital Market & Required for some companies & NA & \\
\hline Malawi & Required for all domestic companies & Not permitted & Malawi Stock Exchange (1995) & 2005 \\
\hline Mauritius & Required for all domestic companies & Required for some, permitted for others & The Stock Exchange of Mauritius (1988) & 2005 \\
\hline Morocco & $\begin{array}{l}\text { Permitted for non banks but required for all } \\
\text { domestic banks }\end{array}$ & Not permitted & Casablanca Stock Exchange (1929) & Jan-2008 \\
\hline Namibia & Required for all domestic companies & Not permitted & Namibian Stock Exchange (1992) & 2005 \\
\hline Mozambique & IFRS permitted & $\begin{array}{l}\text { Required for banks and large companies from } 2010 \\
\text { and Medium-Sized } 2011\end{array}$ & Bolsa de Valores de Moçambique (1999) & 2007 \\
\hline Sierra Leone & Required for all domestic companies & Required for some, IFRS for SMEs for others & NA & 2005 \\
\hline South Africa & Required for all domestic companies & IFRS permitted or IFRS for SMEs & Johannesburg Stock Exchange (1887) & 2005 \\
\hline Swaziland & IFRS permitted & Not permitted & Swaziland Stock Exchange (1990) & \\
\hline Tanzania & Required for all domestic companies & Required for international companies & Dar Es Salaam Stock Exchange (1998) & 2005 \\
\hline Uganda & IFRS permitted & Not permitted & Uganda Securities Exchange (1997) & 2005 \\
\hline Zambia & IFRS permitted & Permitted & Lusaka Stock Exchange (1994) & 2005 \\
\hline Zimbabwe & IFRS permitted & Not permitted & Zimbabwe Stock Exchange (1896-1993) & 2005 \\
\hline
\end{tabular}

Sources: Deloitte (2011), World Bank (2010a), Smith et al., (2002), Kenny and Moss (1998), ASEA (2011), Warsame (2006) and eStandards forum (2010). 
Appendix 2: Summary of the Secrecy Index

\begin{tabular}{|c|l|l|l|}
\hline & Index & Definitions & Mathematical Notation \\
\hline & SECRECY & $\begin{array}{l}\text { Countries which are highly ranked in terms of uncertainty } \\
\text { avoidance and power distance and lower in individualism and } \\
\text { masculinity are more likely to be secretive. }\end{array}$ & SEC = UA +PD-IND \\
\hline 1 & Uncertainty Avoidance & $\begin{array}{l}\text { The extent to which the members of a society feel } \\
\text { uncomfortable with uncertainty and ambiguity. }\end{array}$ & UA \\
\hline 2 & Power Distance & $\begin{array}{l}\text { The extent to which people accept an unequal distribution of } \\
\text { power in institutions or society. }\end{array}$ & PD \\
\hline 3 & $\begin{array}{l}\text { Individualism versus } \\
\text { Collectivism }\end{array}$ & The extent to which individuals are integrated into groups. & IND \\
\hline
\end{tabular}

Sources: Hope et al. (2008), Gray (1988) and Hofstede (1980, 2001). 
